\title{
Para além das evidências do presente (apresentação ao artigo de Marc Augé)
}

\author{
Edemilson Antunes de Campos
}

Quais as consequências para a humanidade das transformaçôes radicais vividas nas últimas décadas, operadas pelas novas tecnologias? Como avaliar as condiçóes de possibilidade da produçáo do conhecimento em um mundo cada vez mais premido pelas exigências do tempo presente? Em um momento em que o mundo parece pequeno, em que as fronteiras entre os países se diluem, como imaginar um futuro promissor para a humanidade?

São esses os desafios enfrentados no artigo de Marc Augé (2007), que agora os leitores têm em mãos na tradução para o português feita por Mariana Mont'Alverne Barreto: Imaginar a humanidade: para uma antropologia dos fins.

Augé foi presidente da École des Hautes Études en Sciences Sociales (EHESS), no período de 1985 a 1995, onde, atualmente, coordena o Centro de Antropologia dos Mundos Contemporâneos. Africanista, realizou suas pesquisas particularmente na Costa do Marfim e no Togo. A partir dos anos 1980, volta-se ao estudo da América Latina, dirigindo seus interesses para as transformaçôes vividas no mundo contemporâneo, notadamente aquelas advindas dos contextos globais.

É nessa linha que o artigo Imaginar a humanidade se situa: um exercício de imaginação intelectual de extrair as consequências das transformações vividas nas últimas décadas pela humanidade. O plano é bem claro:

nossa proposta aqui é menos de tentar imaginar nossos próximos assombros, do que de sublinhar a nova relaçáo com o tempo criada pelos humanos com a "aceleração" de sua história. Há um ou dois decênios, o presente tornou-se hegemônico (p. 223).

Ora, nossa relação com o tempo na atualidade é marcada pela presentificação, uma espécie de vida na imanência, na superfície, característica de um tempo marcado pelo consumo e pela tecnologia: "mundo da imanência onde a imagem remete à imagem e a mensagem à mensagem; mundo para consumo rápido [...] mundo para consumir, mas não para pensar” (p. 223).

É daí que Augé vê a ambivalência de nosso tempo: de um lado, o mundo do consumo, da abundância de produtos e objetos, que opera com uma lógica da imanência e, de outro, a ciência, cujos avanços expressos pela técnica marcam de forma definitiva o tempo presente. É nesse contexto que se delineiam os contornos de nossa cosmotecnologia, na qual o consumo e a técnica se colocam como um fim, definindo e orientando as relaçóes mantidas em seu interior.

Augé avalia, assim, as fragilidades de nosso tempo, no qual as possibilidades transformadoras estão cada vez mais rarefeitas, exigindo uma mudança de escala de percepção e avaliação, na qual se recusa as "falsas evidências de um presente hegemônico" (p. 223).

Mas, como avançarmos para além das evidências do presente? A resposta, Augé a encontra no apelo à imaginação. E aqui as ciências humanas têm uma contribuição fundamental, na medida em que, ao contrário das chamadas ciências duras, elas são, ao mesmo tempo, determinadas pelos contextos histórico-sociais e fazem destes seus objetos de estudo. Nesse sentido, a vocaçáo das ciências humanas é a de desconfiar de toda e 
qualquer evidência, cujas fórmulas consagradas, tais como "o fim da historia", "as leis do mercado", podem petrificar o pensamento, evidenciando a tirania do presente.

É nesse universo regido pela cosmotecnologia que a vocação crítica das ciências humanas se faz importante, ao revelar as determinaçóes contextuais sobre a produção científica, de maneira que a ciência passa pelo crivo das discussóes éticas e da história. Como afirma Augé: "não simplesmente no sentido de que as consequências da ciência e suas aplicaçóes possam colocar problemas éticos [...], mas no sentido dos objetos da ciência terem se tornado objetos históricos" (p. 226).

Dentro dessa cosmologia na qual impera a técnica e o consumo, reificando as formas presentes, a constituição de uma antropologia dos fins se torna essencial:

Essa situação [é] intelectualmente interessante, [pois] em minha opiniáo, pode ser apreendida com uma eficácia peculiar se tentarmos observá-la em escala antropológica: a partir de pequenas unidades, mas nas quais se fazem sentir os efeitos do novo contexto, que é o contexto planetário (p. 228).

A antropologia pode, assim, descortinar as lógicas que regem os comportamentos na atualidade "sob a condição, porém, de que o estudo de seus respectivos microcontextos e seu contexto global recaia mais precisamente sobre as finalidades das quais eles são, ou não, portadores" (p. 228).

Diante dos impasses que colocam em questão o futuro da humanidade, Augé vê na educação a possibilidade de construção de uma utopia que reúna as forças mobilizadoras presentes na atualidade, dentro de um contexto em que jamais a ideia de que todos nós pertencemos à mesma humanidade esteve tão presente. Nas palavras de Augé:

Os mais oprimidos dos oprimidos têm consciência de pertencer ao mesmo mundo que os mais abastados e os mais poderosos - e inversamente. Jamais, no fundo, os homens estiveram em melhor situação para se pensar como humanidade. Mas jamais, também, as tensóes atribuídas à desigualdade de posiçóes de poder e riqueza foram tấo fortes. Nem o heroísmo, nem a generosidade, nem a consciência estão ausentes de qualquer grupo que seja; mas elas não são únicas, se misturam às relaçóes de força, às evidências do presente, às preguiças e pavores da imaginação. São essas misturas que nos é necessário explorar concretamente, em detalhes, para saber se a utopia do mundo sem Deus, sem medo e sem injustiças, de um mundo forte para assegurar o bem-estar de todos e não se consagrar apenas à aventura da ciência possui ainda alguma força mobilizadora (p. 231-232).

É dentro desse programa que o leitor poderá se dedicar à leitura desse artigo vigoroso e avaliar as possibilidades de constituição de uma antropologia dos fins que, para além das evidências do presente, restitua à humanidade o controle de seu destino.

\section{Referências bibliográficas}

AUGÉ, Marc. Imaginer l'humanité. Pour une anthropologie des fins. Divinatio, Sofia, n. 25, p. 35-51, spring/ summer, 2007.

autor Edemilson Antunes de Campos

Doutor em Ciências Spcoaos/UFSCAR e Pós-doutorado/EHESS, França

Professor da Escola de Artes, Ciências e Humanidades/USP

Recebida em 10/11/2009

Aceita para publicação em 27/11/2009

cadernos de campo, São Paulo, n. 18, p. 219-220, 2009 